\title{
河川の生息環境評価手法に関する一考察 AN ATTEMPT TO IMPROVE HABITAT EVALUATION METHOD FOR AQUATIC LIVES IN UPSTREAM RIVER REACHES
}

\author{
原田守啓 1 ・藤田裕一郎 2 - 深谷治由 ${ }^{3}$ \\ Morihiro HARADA, Yuichiro FUJTTA and Haruyoshi FUKAYA \\ 1学生会員 岐阜大学大学院 土木工学専攻（†501-1193 岐阜県岐阜市柳戸1-1） \\ 2正会員 工博 岐阜大学教授 土木工学科（†501-1193 岐阜県岐阜市柳戸1-1） \\ 3 愛知県刈谷市道路建設課（广448-8501 愛知県刈谷市東陽町1-1）
}

\begin{abstract}
To improve a habitat evaluation method known as PHABSIM, we discussed the conventional preference curves that express aquatic lives' inclinations to specific physical properties of fluvial environment. and proposed a new parameter named 'weight exponent' for the preference curves reflecting degree of each parameters' influence on aquatic. Then we estimated the flow field of a study site in an upstream river reaches by an existing numerical model to apply the conventional model and the model proposed with the weight exponent.

As results, we confirmed the superiority of the weighted PHABSIM model to evaluate the habitat suitableness, especially in the region of high population density. We think, a directivity for improvement of the PHABSIM model was presented.
\end{abstract}

Key Words : PHABSIM, WUA, preference curve, suitability index, weight exponent

\section{1.はじめに}

河川における水中生物の生息環境評価手法として一般 に受け入れられつつあるPHABSIM (Physical Habitat Simulation)は, IFIMの枠組の一部として, 正常流量を 多分野間の妥協点として見出すための役割1) から従来 WUA (Weighted Usable Area)が生息場の評価指標とされ ている. しかし，河川生物の総合的・普遍的な生息環境 評価が求められている今日においては, WUAによる評価 は必ずしも最適の方法とはいえなくなってきている．ま た, 空間が持つ生息場としてのポテンシャルを水中生物 の視点に立って記述するためには, 水中生物が生命や種 を維持していく上での重要課題である外敵からの安全, 出水時・低水時の避難, 食餌, 休息, 繁殖などの要素を 含めた評価が必要である. 既に辻本ら ${ }^{2)}$ は同椂の観点か ら，目的に応じて利用される場の連結性を検討している が, 本研究では, その基礎はやはり選好曲線の的確な評 価にあると考え, 岐阜県根尾川上流域において行ってき た生物生息状況と物理環境の現地調査 ${ }^{3,4}$ に基いて, 各指 標毎に作成される選好曲線(Preference curve)に関して 現地の生息状況で観測されるばらつきについて考察を加 え，それを選好曲線に指数による重みとして付加した
PHABSIMモデルを提案する.ついでこれらのモデルの改 善点に言及する.

\section{2. 従来のPHABSIMモデルに関する考察}

\section{(1)選好曲線に関する考察}

従来のPHABSIMモデルでは，対象とする生物種が特定 の物理指標に対して有する嗜好を，0から1の值を持つ適 正指数（Suitability Index）を被説明変数, 物理指標 を説明変数として表した選好曲線によって表現している. さらに中村ら ${ }^{5}$ はこれらの選好曲線（適正基準）を，現 地観測された生息密度に基づくものを第几種適正基淮, さらに物理指標の分布頻度を用いて補正したものを第III 種適正基準として区別している.

しかしながら, 本来生物が空間を把握する際には個別 の要素に対する嗜好だけでなく，いくつもの要素に関す る総合的な判断が関与しているはずである.したがって, 各々の選考曲線は生物の嗜好に独立したものではなく， 複数の物理指標で表現される多次元空間における生物嗜 好性分布の射影を正規化したものであると考えられる. これが，一指標に対する生物の生息状況にばらつきが見 られるのが主要因であると思われる。 
このような選好曲線の定義に関する議論はPHABSIMモ デルの概念の根底にまで及ぶものであり，今後より発展 した議論に繋がることが期待される.

\section{(2) WUAに関する考察}

従来のモデルでは，対象領域に複数の計算セルを設定 し, 各セルにおける物理指標の值（流速・水深・底質 等）をそれぞれの選好曲線に代入することにより得られ る適正指数の積である合成適正指数にセル面積を乗じて 得られるWUAによって生息環境を評価している.

WUA用いて生息環境評価を行う利点は，本来の用途 である，流量を漸次変化させて生息適正場の増減をみる IFIMの場合や，マクロな生息領域の評価のように，条件 の違いによる比較が容易に行える点にある.

しかし，例えば人工構造物の設置による生息環境への 影響を評価するなど，比較的狭い範囲を対象とするケー スでは，WUAではなく適正指数の平面分布で評価を行う 方が傾向の的確な把握が容易であるとともに，生息環境 の変化の度合いを検討する上でも有益であろう。

以上のように生息環境評価の目的に応じて，WUA と適 正指数を使い分けることが重要であり，本研究では，従 来モデルと次に述べる重み付きPHABSIMモデルとを適用 した場合についての生息状況の適合性を比較することが 目的の一つであるため, 適正指数を用いる.

\section{3. 重み付きPHABSIMモデル}

\section{(1) 重み指数について}

一般に，選好曲線は，生息状況と非生物環境の現地調 查と既往の文献に基づいて作成されるが，これらに基づ いて, 各物理指標に対して独立した選好曲線を一意的に 定義することには不確実性が伴う。なぜなら，様々な要 素が介在する現地では，理想的な条件付きサンプリング の実施は不可能であり, また, 前述の通り生物種の嗜好 性に対して各物理指標の独立性は保証されていない，

そこで本研究では, 現地調査から回帰的に作成される 選好曲線は，生物がその物理指標に対して示寸平均的な 挙動を示したものであると考え，特定の物理指標が生物 に対して有する支配性を他の物理指標に比較して示しう る要素を従来のモデルに付加する方法について以下のよ うに考えた。

生息状況と特定の物理指標の相関において，ばらつき が大きいほどその物理指標の支配性が低いと判断し，そ れを重みとして合成適正指数に反映させる方法として, 各指標ごとに算出される適正指数にかかるべき数を導入 した. すなわち, この指数を, 特定の物理指標が他の物 理指標に比して生物に対する支配性を意味していること から重み指数（Weight Exponent）と呼ぶこととした.

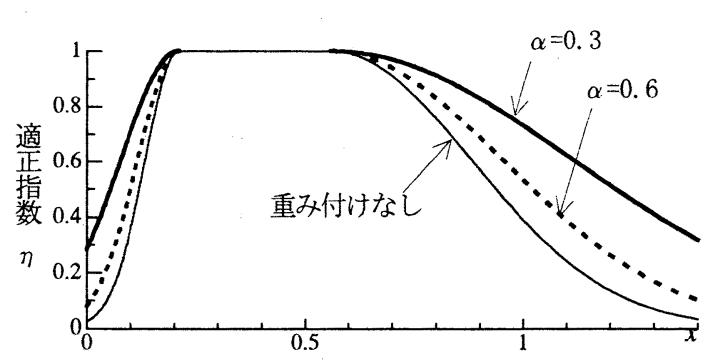

図-1 重み指数の変化による選好曲線の応答

\section{(2) 重み付きPHABSIMモデルの一般形}

上の議論から, 空間の各点における合成適正指数 (C.S. I. ) は次の式で表現される.

$$
\text { C.S.I. } \cdot_{a t i}=\prod_{j=1}^{n}\left\{\eta_{j}\left(x_{j}\right)\right\}^{\alpha_{j}}
$$

ここに, $i$ は計算点（セル）の番号, $\eta_{j}$ は物理指標 $j$ に関する選好曲線を示し, $i$ における物理指標值 $x_{j}$ を代入して各適正指数を算出している. またここで, $\alpha_{j}$ は物理指標 $j$ についての重み指数である.

\section{（3）重み指数の特性}

0から1の適正指数を值として持つ選好曲線は，重み指 数 $\alpha$ が0に近づくにつれて, 図-1に模式化したように, $\eta=1$ の直線に漸近していく.これは, 物理指標の值 の変動に対する選好曲線の応答が鈍くなることを表して おり，生物種に対して特定の物理指標に有する支配性を， 最終出力である合成適正指数に反映させることが可能で ある。

\section{4. 河川上流域における生息環境調査の概要}

\section{(1) 調査地の概要}

木曾川水系捍斐川支川根尾川の河口より約 $80 \mathrm{~km}$ ，標高 約 $160 \mathrm{~m}$ の岐阜県揖斐郡根尾村板所地先にある，250mの区 間を調査地に選定し，生息環境調査を行ってきた。

調査区間の右岸側は岩が露出し，その上は豊かな河畔 林である. 一方, 左岸側は河原に続いて護岸があり, 河 岸天端は国道157号線として利用されている.

調査区間の河床形状は，図-2のように自然の瀬・淵構 造となっていて，上流から勾配 $1 / 100$ の平瀬が勾配 $1 / 60$ 前後の早瀬となって，右岸の突出する岩に支配されてい るMR型の淵に落ちこみ，その下流は勾配が緩く河床材料 の細かい平瀬となっている. 平瀬の左岸は大きな石を中 心に構成された河原となっている.

\section{(2) 調查内容}

生息環境を明確にするために以下の調査を行っている. 


\section{a) 生物調查}

魚類の生息状況を目視と投網による捕獲によって調査 し, 個体数, 体長, 行動等を記録している.

底生生物については，50cm角コドラード付きサーバ ネットと用いたキックアンドスイープ法により，種構 成・個体数等を調査している.

b)物理環境調查

光波測距儀による地形測量, 3次元電磁流速計 (ALEC 製ACM-300, $\phi=20 \mathrm{~mm}$ ）を用いた流速の測定，写真撮影に よる河床表層状況定点調査を行っている，また，調查地 から約 $4 \mathrm{~km}$ 上流の広頂堰に自記水位計を設置して，流況 の年間変化を把握している.

\section{5. 選好曲線の作成と重み指数の決定}

\section{(1) 選好曲線の作成}

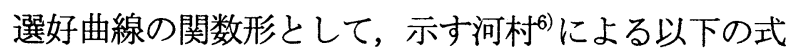
を採用した。

$$
\begin{array}{lll}
\eta=\exp \left[-C_{3}\left(x-C_{1}\right)^{2}\right] & \text { at } & x \leq C_{1} \\
\eta=1 & \text { at } & C_{1} \leq x \leq C_{2} \\
\eta=\exp \left[-C_{4}\left(x-C_{2}\right)^{2}\right] & \text { at } & C_{2} \leq x
\end{array}
$$

適性指数 $\eta=1$ となる領域 $C_{1} \leq x \leq C_{2}$ が，対象生物 の生息に最も適した物理指標の範囲であり， $\eta$ はその両 側で減少する.

現地調査で得られた情報に基づき上式の定数 $C_{1} \sim C_{4}$ を以下の方法により決定した.

(1)生息密度の最大值の $80 \%$ 以上の密度が確認された物理

指標の範囲の下限と上限をそれぞれ $C_{1}$ と $C_{2}$ とした。

(2)生息可能な物理指標の上限值・下限值を現地調査並び

に文献調査から決定し, $C_{3}, C_{4}$ を逆算した。

この選好曲線は前述の中村ら ${ }^{5)}$ の第 II 種適正基準に当た るが，調査地点を評価の対象にしているので，分布補正 を行っていない.

\section{（2）重み指数の決定}

重み指数の決定方法としてはいくつかの方法が考えら れるが, 試行錯誤の結果, ここでは, 重み指数の意義に 背かず，かつ取り扱いの統一性と簡便さを考えて，生息 密度と物理指標との2次近似曲線を求めた際の決定係数 をそのまま重み指数として用いる.

\section{6. 調査区域の水理環境の推定}

\section{(1) 数值計算の概要}

各生物種の生息状況を調查区間全体に亘って評価する
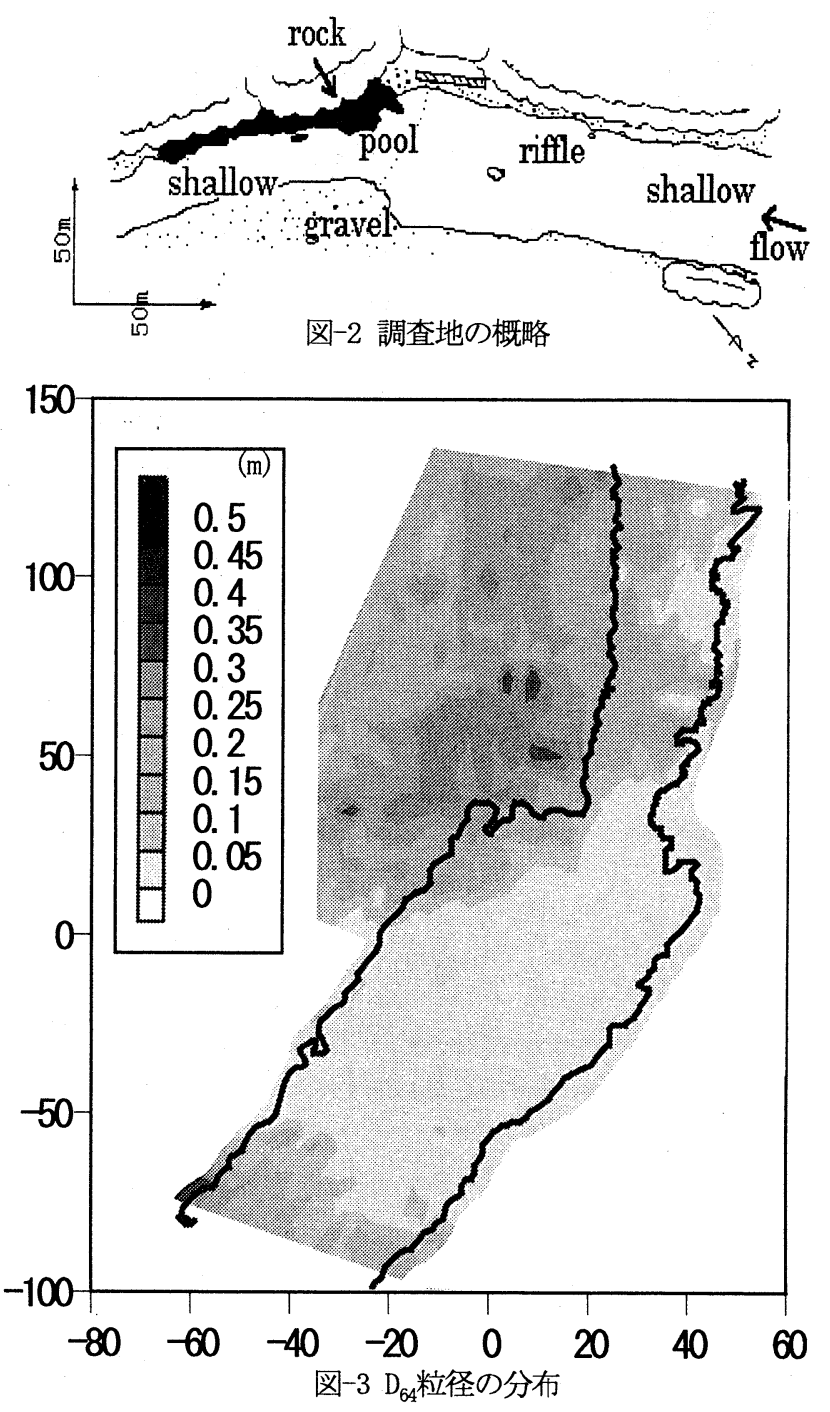

ために，流況を2次元数值シミュレーションを適用して 平面的に推定したが，研究の対象とする区間は流路形状 が複雑であるので，一般座標系の境界適合格子を用い， 長田 ${ }^{7)}$ らの平面2次元非定常流れの数值解析モデルを援用 して計算を行った.

境界条件として，99年10月の現地調査で得られた流量 約 $10 \mathrm{~m}^{3} / \mathrm{sec}$ 上流端に, 下流端に観測した一定水位を与 光，各計算横断面を通過する流量がほぼ定常となり次第 計算を打ち切っている.

また, Manningの粗度係数は，99年10月に現地撮影し た約200箇所の河床写真から粒径加積曲線を作成し, 図一 3 に示した $\mathrm{D}_{64}$ 粒径の平面分布を得て，これを各計算格子 点に内挿して, Manning-Stricklerの式で与えている.

しかしながら，早瀬では石砅が水面から露出している 個所も多く，ここでは上述の方法では不適切と思われる ので，測定した流速と局所河床勾配から逆算した粗度係 数を用いている.

同様に格子点の河床高は，図-4に示した現地での測量 結果を内挿して求めた.

なお，“計算格子は，流れ方向を $\xi$ 軸，左右岸方向に $\eta$ 軸をとり，まず左右岸・上下流端に $\xi=35, \quad \eta=31$ の格子 

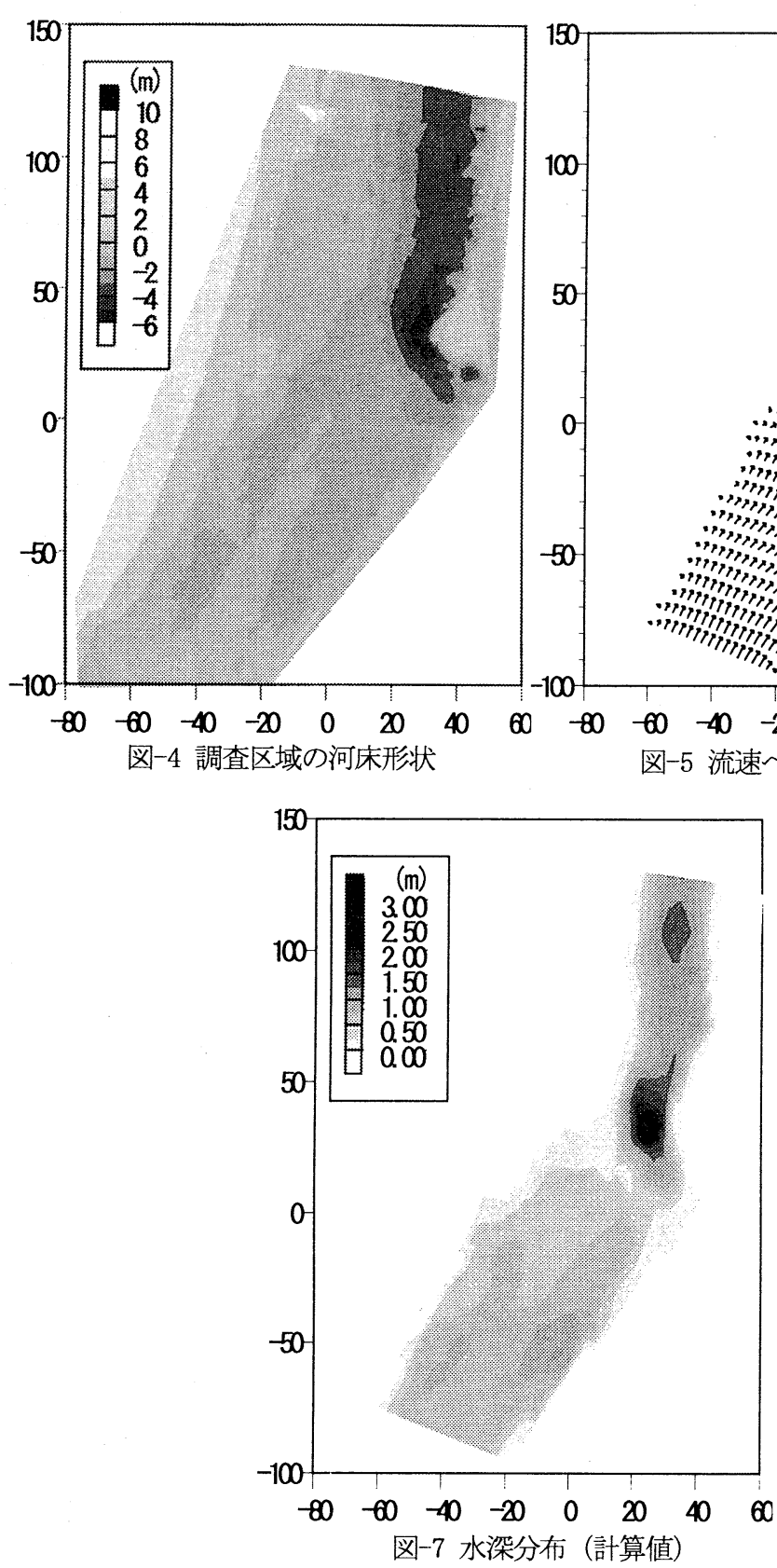

分布を与えた後, 代数式によって収束計算を行って格子 を形成した ${ }^{8), 99}$.

\section{（2）計算結果とその検討}

\section{a) 流速}

図-5に計算流速ベクトルの分布図を，図-6に現地での 実測流速を示す． $\mathrm{y}=30 \mathrm{~m}$ 付近の淵から下流側は概ね合致 していて，早瀬からMR型の淵に流入する地点の左岸側 $(\mathrm{x}=20 \mathrm{~m}, \mathrm{y}=40 \mathrm{~m})$ 付近には，現地で観察されている逆流域 も現れている.

$\mathrm{y}=-50 \sim 30 \mathrm{~m}$ の早瀬部分において実測では; "河道中央に 形成された中州状の堆積部の影響による流れの二分傾向 が明膫である．計算結果ではそれが微弱であり，また， 上流では，実測流速の絶対值が大きくなっている.

この理由は，流速の測定方法にあると考えられる．前 述のように石碟が水面から露出している個所も多く見ら れる早瀬部では，石礫の間隙で流速を測定するために，
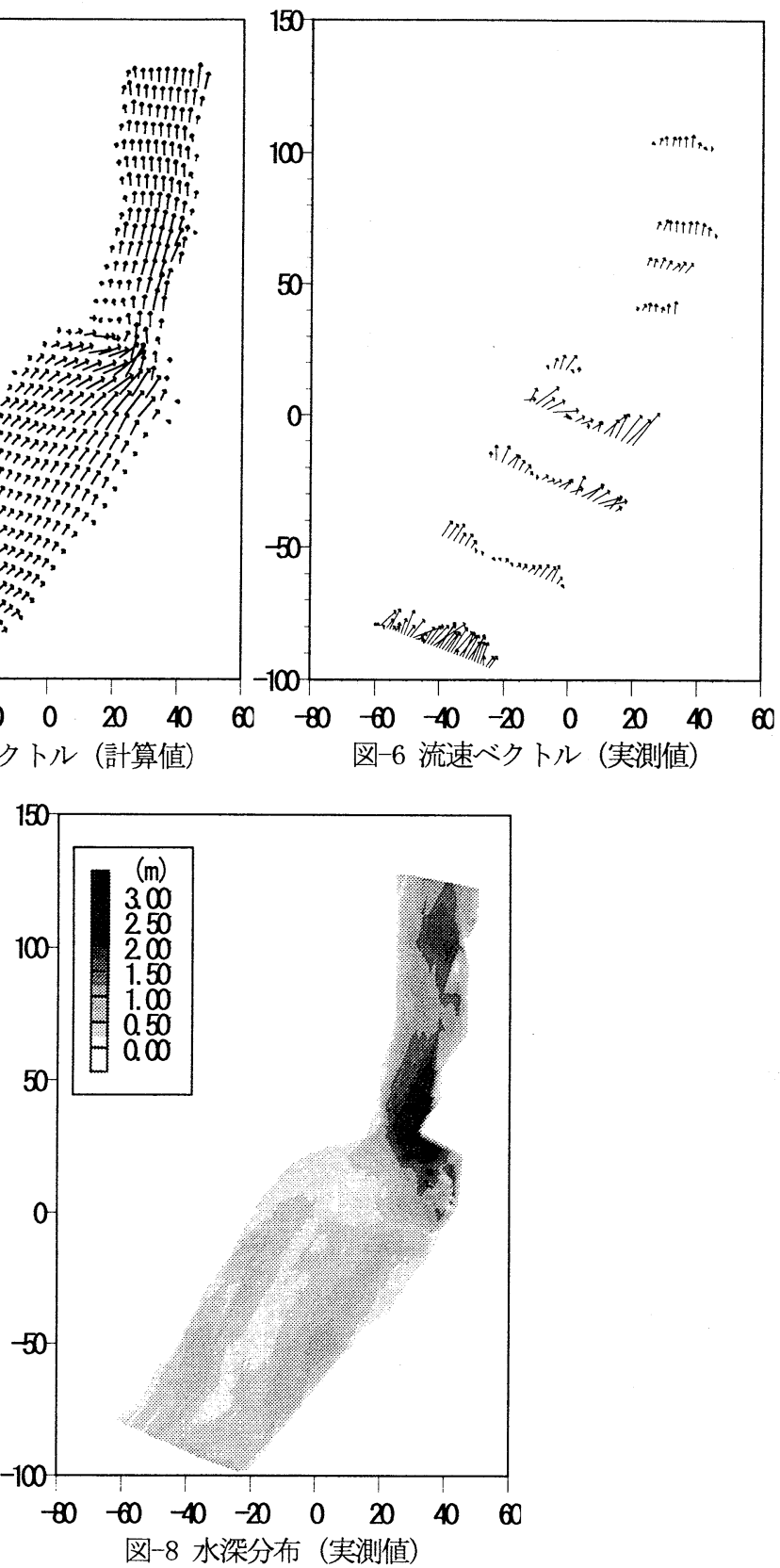

平均化された流速に比較して実測值は大きなもの になったとみられる.

また，計算で早瀬の分流傾向が弱い原因としては，河 床形状を計算格子点に内挿した際に，その流路形状を平 滑化してしまっていること，及び，調査区間直上流の深 く湾曲した個所を計算領域に含めなかったために，主流 が右岸側に偏った上流区間の影響が計算では配慮されて いないことの，2点が考えられる.

これらの事実は，現地河川の流況を再現する上で，用 いる数值計算モデルのみならず，生息環境評価でも入力 情報に現地の流況を支配する要素が十分包含されている かを見極めることの重要性を示唆している.

b) 水深

図-7に計算結果による水深分布図，図-8に現地の水深 分布を示す.

流速の計算結果と同様に，淵から下流側の区間ではよ く一致しているといえる. しかしながら，やはり早瀬区 

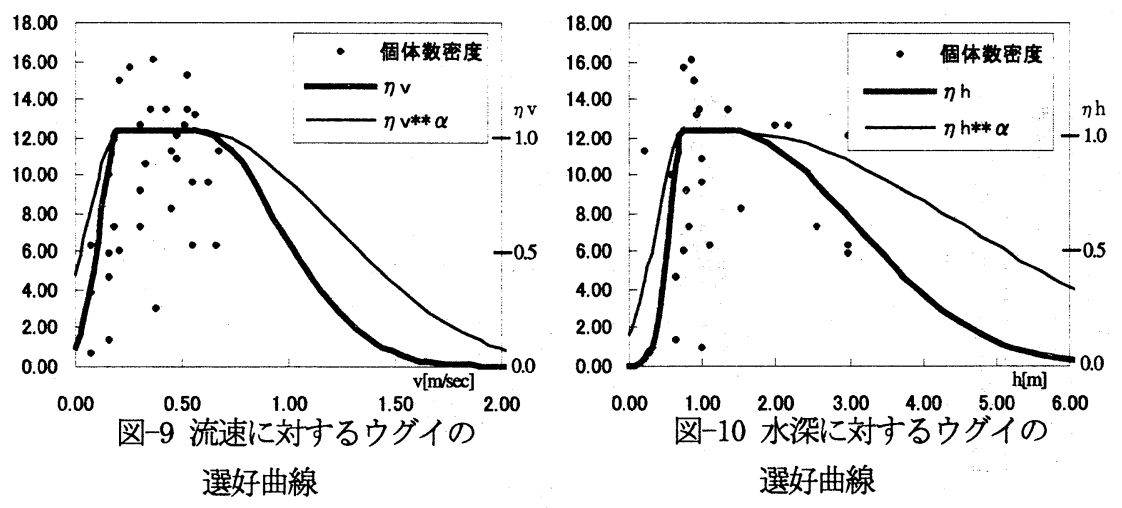

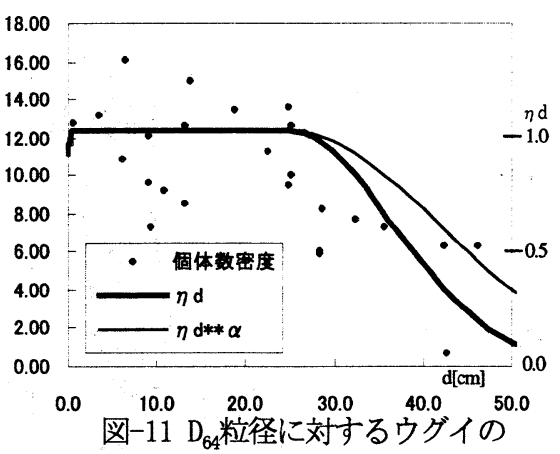

選好曲線
間での計算值は全体に平滑化されており，とくに淵への 流入地点の左岸側 $(\mathrm{x}=0 \mathrm{~m}, \mathrm{y}=20 \mathrm{~m})$ では, 水深が一様に浅 いという結果となっている. この推龍原因としては, 早 瀬の流れを特徴づけている粗石が持つ流水抵抗と, 流水 断面積减少効果が計算モデルに十分には反映されなかっ たことが考えられる.

\section{7. 現地の生息状況とモデルの適用結果の比較}

これまでの検討によって得られた選好曲線と重み指数， 及び数值計算により推定された水理量を用いて, 合成適 正指数による生息場の評価を試みる.

\section{(1) 選好曲線}

ここでは魚類の中でも，調査河川において優先種であ るウグイについて，99年10月の生息状況から作成した選 好曲線を図-9，10，11に示す．また，表-1にそれらの選 好曲線を規定する定数と重み指数の一覧を示す.

\section{(2) 合成適正指数の算出}

流況の再現のための数值計算で用いた格子の各点にお けるウグイの合成適正指数を，次の式によって算出する.

(ModeI_1) 従来のPHABSIMモデル

$$
C S I .=\left\{\eta_{v}\left(v_{i}\right)\right\} \times\left\{\eta_{h}\left(h_{i}\right)\right\} \times\left\{\eta_{d}\left(d_{i}\right)\right\}
$$

\section{(ModeI_2) 重み付きPHABSIMモデル}

$$
\text { C.S.I. }=\left\{\eta_{v}\left(v_{i}\right)\right\}^{\alpha_{v}} \times\left\{\eta_{h}\left(h_{i}\right)\right\}^{\alpha_{h}} \times\left\{\eta_{d}\left(d_{i}\right)\right\}^{\alpha_{d}}
$$

ここに， $\eta$ と $\alpha$ は，それぞれ添え字で示した物理指標 $\left(v:\right.$ 流速, $h$ :水深, $d: \mathrm{D}_{64}$ 粒径)に関する選好曲線と重 み指数である.これらに各格子点 $i$ における值等を代入 してそれぞれの適正指数を得る.

n個の適正指数の積に対してn乗根をとり合成適正指数 を基淮化して議論すべきであるという提案10)がなされて いる. 確かに, 異なった数の指標を用いている場合の比 較にはその必要性が考えられるが，この方法では，ある 指標で適正指数が下がり, 別の指標によってさらに適正
表-1 ウグイ選好曲線の定数一覧

\begin{tabular}{|c|c|c|c|}
\hline & $\eta_{v}$ の定数 & $\eta_{h}$ の定数 & $\eta_{d}$ の定数 \\
\hline$C_{1}$ & 0.21 & 1.00 & 0.05 \\
\hline$C_{2}$ & 0.56 & 1.50 & 0.10 \\
\hline$C_{3}$ & 57.27 & 2.30 & 42.14 \\
\hline$C_{4}$ & 3.26 & 0.13 & 14.39 \\
\hline \hline$\alpha$ & 0.374 & 0.295 & 0.486 \\
\hline
\end{tabular}

指数が下がる状況が反映されにくいことも否めない等, 検討の余地があると思われるため, 本研究では基隻化は 行わない.

\section{（3）現地の生息状況との比較}

現地でのウグイの生息状況を図-12に，Model_1と Model_2によって算出した合成適正指数の分布を図-13, 14にそれぞれ示す。

現地の生息状況を見ると, 渒周辺 $(\mathrm{x}=20 \mathrm{~m}, \mathrm{y}=40 \mathrm{~m})$ と平 瀬下流 $(\mathrm{x}=35 \mathrm{~m}, \mathrm{y}=110 \mathrm{~m})$ に多くの個体が生息しているが， 重み付けを行わなかったMode1_1では, 淵周辺の適正指 数が低くなっており, 現地の状況との一致がやや劣って いる. 重み指数を付加したModel_2は，特に個体数が多 く確認されている2地点において適正指数が高くなって おり，より現地の状況を評価できているといえる.

Mode1_1と比較すると, Mode1_2は全体的に適正指数が 高めになっているが，これは主に水梁の影響が緩和され ているためであると考えられる. 特に水深が $3 \mathrm{~m} か ら 2 \mathrm{~m} に$ 徐々に浅くなっている淵から平瀬に移行する区間では, 適正指数の上昇が著しい. 早瀬においても, 同様の理由 から，やや適正指数が上昇している.

早瀬においては, 流速に重み付けを行うことによる適 正指数のより以上の変化が期待されたが，流況推定の計 算結果の検討で述べたように, 早瀬の流況が平滑化され たために，期待したほどの相違は得られなかった。

両モデルに共通して, 現地で生息が確認されていない 地点においては適正指数が低く, 生息適正の下限が評価 できていると思われる. 一方, 多くの個体の生息が確認 されている地点では, Mode1_2の方が現地の状況を良く 評価できており，生息適正の上限付近の評価において Mode1_2の有効性を示すことができた. 


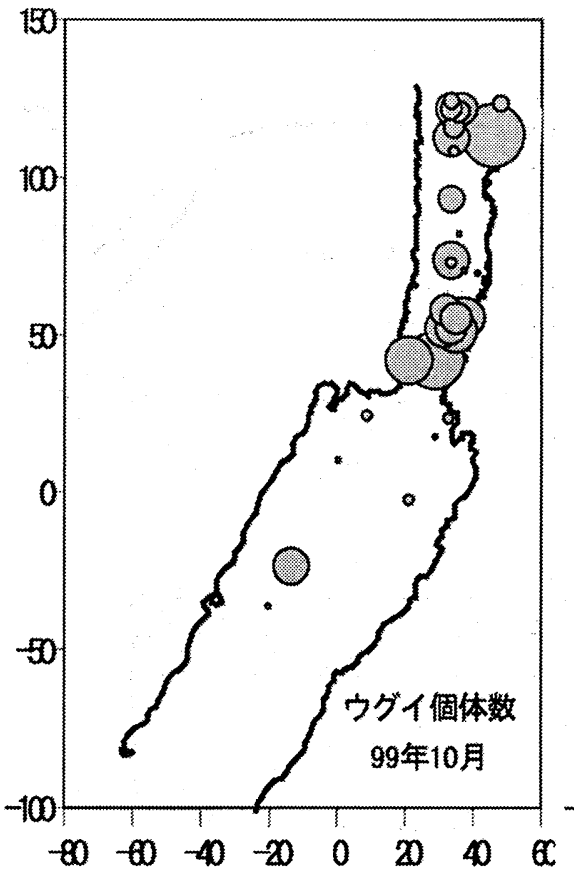

図-12 生息状況調查結果

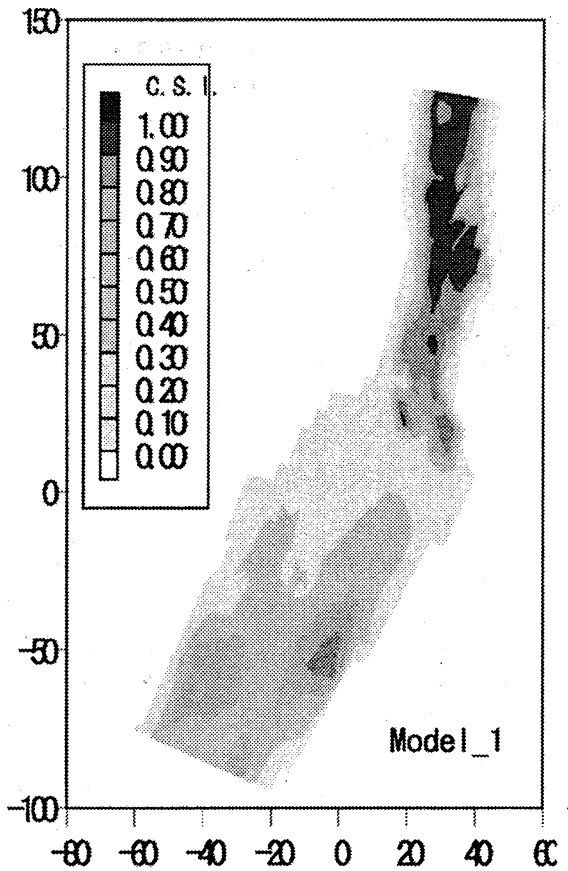

図-13 従来モデルの適正指数分布

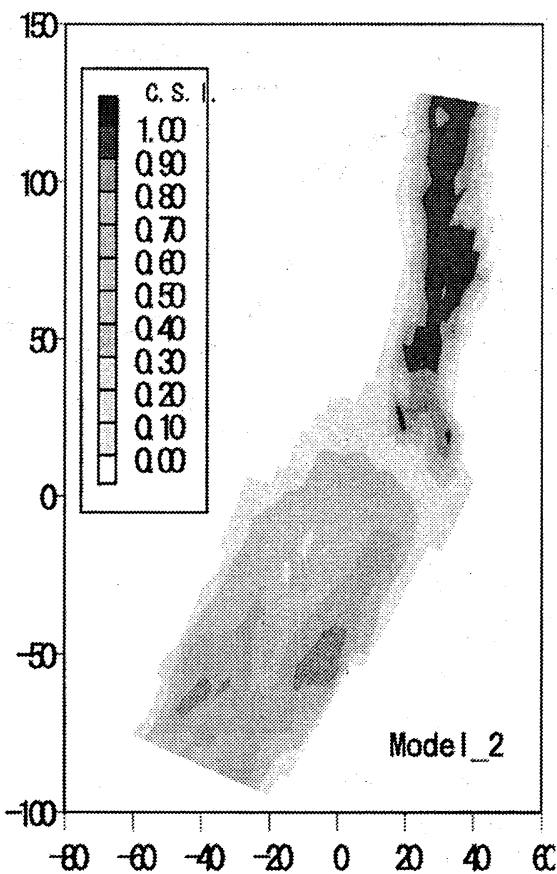

図-14 重み付きモデルの適正指数分布

\section{8. おわりに}

本研究では, 最初に従来のPHABSIMモデルにおける選 好曲線の意義とWUAの考え方について再考察し，その議 論に基づいて重み付きPHABSIMモデルを提案した。つい で, 河川上流域の現地調査結果等に基づいて選好曲線と 重み指数を具体的に示し, 一般座標系による数值計算モ デルで推定した平水時の平面流況と路床面の実測結果と を組合せて，適正指数の形で生息環境を評価し，調査結 果と比較して考察を加えた.

以上から，主要な結論を述べると，

(1) PHABSIMモデルを再考察し，モデルの内部要素であ る選好曲線の概念を明確化した。

(2) 上の考察から, 従来のPHABSIMモデルの問題点であっ た, 各物理指標が同等の支配性を持つとして独立して 扱っている点に対し，モデルに重み指数を導入すること により, 一つの方向性を示した.

（3）重み付きPHABSIMモデルは，生息最適範囲の上限にあ たる水域付近において，現況をよく評価できることを確 認した。

今後は, 重み指数の決定方法や, 早瀬の流況の推定に ついて, 本研究で得られた考察をもとに検討を進めるほ か，各生物種の食餌・休息等の行動や生活史を反映した より現実的な生息環境評価を行うための考察を深めてい きたい。

謝辞 : 本研究を行うにあたり, 岐阜大学工学部の水上精 栄技術官, 同卒業生の㝋石雅司氏, 小野敏雄氏に御尽力 を頂いた. ここに記して謝意を表したい.

\section{参考文献}

1)T. ワドゥル:IFIMーの招待, (財) リバーフロント整備セン ター,pp. 4-22, (1996)

2)辻本哲郎, 田代喬, 伊藤壮志: 生活圈の連結性に着目した魚類 生息環境評価法の提案と河川内微地形の役割評価, 河川技術 に関する論文集，pp. 167-172, (2000)

3) 水上精栄ら: 根尾川上流域の生態系に関する調查(1), 岐阜大 学工学部研究報告第48号, 岐阜大学工学部, (1998)

4) 原田守啓ら:根尾川上流部に生態系に関する調查・研究 (2), 岐皁人学工学部研究竍告第50号, 岐皁人学工学部, (2000)

5) 玉井信行, 奥田重俊, 中村俊六: 河川生態環境評価法, 東京大学 出版会, pp. 95-102, (2000)

6) 自然共生河川研究所: 中部の河川におけるIFIM手法の適用研 究(1)および(2), (1996, 1997)

7)長田信寿:水工学における計算機利用の講習会講義集, 土木学 会水理委員会基礎水理部会, pp. 61-76, (1999)

8) 藤井孝蔵: 流体力学の数值計算法, 東京大学出版会, pp. 189190, (1994)

9) 数值流体力学力学編集委員会: 格子形成法とコンピュータグ ラフィックス, 東京大学出版会, pp. 21-26, (1995)

10）辻本哲郎, 増田健一, 寺本敦子, 田代喬:試験谌水時のダム下 流河道の生息環境の変質とその復元のためのフラッシュの効 果, 河川技術に関する論文集, pp. 223-224, (1999)

(2000. 10. 2受付) 